gleichzeitigem Anstieg der Neutralfette und der freien Fettsäuren im zentralvenösen Blut. Diese Ergebnisse finden ihre Erklärung in den morphologischen Lungenveränderungen: Odem von Gefäßwand, Perivasculärraum und Interstitium, Verbreiterung der Alveolarsepten und Mikrothrombosierung der Lungencapillaren.

\title{
58. Die Bedeutung der Lungenkontusion für die Prognose des Kombinationstraumas
}

\author{
V. Zumtobel, * H. Standfuss und G. Haffiner-Köln
}

\section{The Importance of Contusions of the Lung in the Prognosis of Cases with Multiple Injuries}

Summary. Of 581 patients with multiple injuries admitted to the Surgical University Clinic, Cologne, over the past seven years, respiration had to be assisted in 224 cases for contusions of the lungs. Of these 224 patients who received artificial respiration, 87 died of their injuries, of whom 58, that is two-thirds, died of the direct or indirect effects of the lung injuries. In three separate age groups (up to 30 years, $31-50$ years and $51-80$ years) there was a significant relationship between the mortality rate due to lung injury and the age of the patients $(10 \%$, $20 \%, 41 \%$, respectively). There exists also a direct relationship between the duration of the artificial respiration and the survival rate, and the period of time that elapsed between the time of the accident and the start of the artificial respiration. Mortality due to lung complications amounted to $16 \%$ in 95 patients where artificial respiration was applied within 12 hours of the injury, $24 \%$ in 86 patients with artificial respiration after 12-24 hours and $53 \%$ in 43 patients receiving artificial respiration after $24-\mathbf{4} 8$ hours. The average duration of the artificial (mechanical) respiration in the surviving patients was 11,17 and 18 days respectively.

On the basis of these observations we recommend that every injured patient whose clinical condition arouses the suspicion of lung contusions should be intubated and given artificial respiration as soon as the first signs of respiratory failure appear and before respiratory failure actually occurs.

Zusammenfassung. In den letzten $7 \mathrm{Jahren}$ wurden an der Chirurgischen Universitätsklinik Köln von 581 Patienten mit Kombinationsverletzungen 224 wegen Lungenkontusionen assistiert beatmet. Von diesen 224 beatmeten Verletzten starben 87 an ihren Verletzungsfolgen, davon 58 , also $\% 3$, an direkten oder indirekten Folgen der Lungenschädigung. In drei verschiedenen Altersgruppen (bis $30 \mathrm{Jahre}$, 31-50 Jahre und 51-80 Jahre) zeigte sich eine deutliche Abhängigkeit der Letalität infolge Lungenschädigung vom Alter der Verletzten $(10 \%, 20 \%, 41 \%)$. Außerdem bestand eine direkte Abhängigkeit der Beatmungsdauer und therlebensaussicht von dem Zeitraum zwischen Unfall und Beatmungsbeginn. Die Letalität infolge Lungenkomplikationen betrug bei 95 innerhalb der ersten 12 Std nach dem Trauma beatmeten $16 \%$, bei 86 nach 12-24 Std beatmeten $24 \%$ und bei 43 nach 24-48 Std beatmeten Verletzten $53 \%$. Die durchschnittliche Beatmungsdauer der Uberlebenden lag jeweils bei 11, 17 und 18 Tagen. Auf Grund der Untersuchungsergebnisse sollte jeder Unfallverletzte mit klinischem Verdacht auf eine Lungenkontusion bereits vor Eintritt einer klinisch manifesten respiratorischen Insuffizienz schon bei den ersten Anzeichen einer Einschränkung der Atemfunktion intubiert und beatmet werden. 